\title{
ZAKAT: CONCEPT AND IMPLICATIONS TO SOCIAL AND ECONOMIC (ECONOMIC TAFSĪR OF AL-TAWBAH:103)
}

\author{
Abdul Wahid Al-Faizin ${ }^{1}$ \\ Taqiyah Dinda Insani ${ }^{2}$ \\ Sri Herianingrum ${ }^{3}$
}

\begin{abstract}
One of the most used methods by Ulamā' to find the laws and wisdoms from Quran is a tafsīr method. This paper seeks to examine and analyze the concept from sūrah alTawbah: 103 - ayah with the more general content related to the concept and function of zakat - by using the tafsir method and how the implication of zakat for the social and economic equality is. The method used in this paper is a qualitative method by using content analysis that combines tafsīr bi al-ra'yi with tafsīr bi al-ma'thūr. By using economic interpretation, the result shows that zakat should be an obligatory system and its management must be done centrally by the government. In this case Baznas can be a representation of the government to perform the task. The study also found that there are two implications of the zakat mentioned in sūrah al-Tawbah: 103. First, التطعير (purification) through which zakat is able to provide social implications of tranquility, security, and harmony. Secondly, التزكية (holy, blooming, blessing and praise) through which zakat has economic implications both in micro aspects (increase in quantity in the economic curve) and macro (increased investment and depletion of poverty and unemployment).
\end{abstract}

Keywords: Zakat, Economic Tafsīr, Social and Economic Equality

JEL Classification: O15, P36, Z12

Received : September 22, 2017

Revised : April 10, 2018

Accepted : May 1, 2018

1. Post Graduate School, Universitas Airlangga, Airlangga 4 - 6, Surabaya, Indonesia, alfaiz165@gmail.com

2. Post Graduate School, Universitas Airlangga, Airlangga 4 - 6, Surabaya, Indonesia, tdindainsani@yahoo.com

3. Post Graduate School, Universitas Airlangga, Airlangga 4-6, Surabaya, Indonesia, sriherianingrum@feb.unair.ac.id 


\section{INTRODUCTION}

Zakat is an important principle in the islamic economics. Zakat in the Islamic economics has two main functions. First, as a tool of worship which giving the individual benefit to the person paying zakat. Second, giving the collective benefit for people in the environment which run the system of zakat (Sakti 2007).

A large body of literatures have attempted to discuss and examine the impact of zakat on poverty by employing modern economic tools (see: Ibrahim, 2006; Mila Sartika, 2008; Irfan Syauqi Beik, 2009; Firmansyah, 2013; Rina Murniati and Irfan Syauqi Beik, 2014; Irfan Syauqi Beik and Caesar Pratama, 2016). On the other hand, Islam has its own scientific khazanah such as Tafsir to explore a concept from the main source, Quran and hadith. Tafsīr is a method used by Islamic scientist in order to explore a concept and wisdom contained in the Quran.

This paper therefore aims to explore the concept and implication of zakat for social and economy by using method that have not been used by the majority of researchers i.e. Tafsìr method. In this case, the object of research is sūrah alTawbah: 103, which verse has more general content than other verses related with the concept and function of zakat.

This paper analyzed the meaning of Lafad mentioned in sūrah al-Tawbah: 103. From that semantic analysis, the authors explore some concepts that exist in sūrah al-Tawbah: 103. This analysis refers to some book of tafsìr both of classical and contemporary books. Similarly, the authors combine the tafsīr bi al-ma'thūr book and tafsīr bi al-dirāyah book.

Based on the background above, the objectives research of this paper are to analyze how the concept of zakat based on sūrah al-Tawbah : 103 is; and how the implication of zakat for the social and economic equality is.

\section{LITERATURE REVIEW}

This section consists of theory and previous studies that support the research.

\subsection{Theory}

\subsubsection{Zakat and Its Position in Islam}

Zakat means البركة والنماء والطهارة والصلاح (blessing, growth, holy, and kindness). While in terminology, zakat has the meaning of a certain part of the treasure that has been required by Allah to be given to the people who are entitled to receive it (mustahiqq). That treasure which taken is called zakat because it can increase its principal treasure and keep it from various danger (Qardawi 1973).

Zakat is perceived highly in Islam since it is one of the pillars which build Islam. This is as mentioned by Rasulullah:

"Islam is based on (the following) five (principles): Syahadat Laa ilaaha illa Allah and (syahadat) Muhammad Rasulullah, to offer the (compulsory congregational) prayers dutifully and perfectly, to pay zakat, to perform Hajj, and to observe fast during the month of Ramadhan" (HR Bukhari)

Allah pairs the command to pay zakat with the command to pray as much as 22 times in Quran. This indicates the crucialty of zakat in Islam. In addition, zakat is a unique and complete system about redistribution (Rivai 2013). Islam regulates quite 
clearly about zakat, therefore it takes a study to understand the function of zakat, so in the implementation zakat become an obligatory system not voluntary system.

\subsubsection{Concept and Methodologi of Tafsīr}

Tafsìr in epistemology means al-Ị̇̄a h al-Tabyīn (clarifying and explaining) (Ayyūb 2004). While in terminology means the study of explanation about the meaning contained in Quran and explore the laws, wisdoms, mau'izah and lessons in it (Yūnus 2002). According to most Ulamä'tafsīr, tafsìr and ta'wīl are two synonymous word.

Generally, there are three forms of Tafsìr, that is (Ayyūb 2004):

a. Tafsìr bi al-Riwāyah or bi al-Ma'thür

Interpreting the Quran with the Quran itself, hadith, or the words of the prophet's friends. The tafsir books that belonging to this type are Tafsir alT,abarī, al-Durr al-Manthūr, Ibn Kathīr, al-Baghawī and many more.

b. Tafsìr bi al-Dirāyah or bi al-Ra'yi

Interpreting the Quran with the tought ( $\left.r a^{\prime} y u\right)$. In this case, $r a^{\prime} y u$ is an Ijtihād which compatible with the basic principles of Ijtihād. It is different with the interpretation which only depends on logic without basic principles of Ijtihād, it is considered blameworthy and can be misleading.

The followings are guidance for people who want to interpret the Qur'an (Suyūṭi 1998):

1. Quoting from Rasulullah with avoid the $d a^{\prime} \hat{\imath} f$ and maud $\bar{u}^{\prime}$ hadith

2. Taking the opinions of the Prophet's friends. It can be done because according to the mufassir, the opinion from the Prophet friends in an absolute like hadith marfü'.

3. Understanding the Arabic grammar and be able to examine the arrangement very well.

4. Knowing some shari'ah basic rules (al-ușūl al-shar'iyyah)

Thus, not everyone can do the interpretation of $b i$ al-Ra'yi. It caused so many people who didn't have basic principle of Ijtihād are very audacious to interpret the Quran as they want. As a result, the interpretations tend to be wrong and misleading. Some of this tafsìr book are Tafsìr al-Jalālain, al-Baidawì, al-Alūsī, al-Khäzin and so on.

c. Tafsìr bi al-Ishārah or Tafsīr al-Ishārī

The interpretation done by tasawwuf people which try to find the wisdom from Quran. Some of Ulama $\bar{a}^{\prime}$ have a different opinion about this tafsìr. Some of them are allowed and the others think it is heretical. Some of this book's type are Tafsìr al-Nisāburì and Tafsìr Rūh al-Ma'āni by al-Alūsì.

Among the forms of tafsìr bial-Ra' $y i$ is interpret the Quran with the modern science such as astronomy, medical, economic, and management. This kind of interpretation leads to a lot of controversy among the Ulamán'. Some are allowed and some are prohibited. Ulama $\bar{a}^{\prime}$ who forbid this interpretation are Shaikh Shaltūt and Sayyid Quț.

On the other hand, Ulam $\bar{a}^{\prime}$ who enables the usage of science to interpret meanings behind the Qur'ain verses are imam al-Ghazālì and al-Suyūṭ̂̀ (Qarāwi 2002). According to al-Ghazāli, generally all the science is included in the deeds and the traits of Allah. While, the Quran explain the substance, deeds, and traits 
of Allah. And the science is not final. In Quran, there is only a global signal to the science.

In these case, there are some things that need attention for people who want to interpret Quran with science, that is (Qarāwi 2002):

1. Hold on to scientific facts not hypotheses. This is very important because when interpret Quran with hypothesis, the interpretation made will vary according to the existing hypothesis.

2. Stay away from self-imposed in understanding of nas. In this case, we are forbidden to impose a Naș of Quran with the meaning we want to conclude. However, we should take some meaning which compatible with the language and the existing Naș editorial flow.

3. Avoid to accusing people are fools.

4. When we interpret Quran with science, do not ever consider Islamic ummah or former Ulamā' are stupid for not be able to interpret as we do.

\subsection{Previous Research}

There are several researches conducted related to the impact of zakat. First, research conducted by Ibrahim (2006) entitled "Economic role of zakat in reducing income inequality and poverty in selangor". The subject of this research is the recipient of zakat in Zakat Selangor Center on nine regencies in selangor, while the object of research is the inequality of income and poverty. By using the Lorenz curve test kits, The Gini coefficient, and the Atkinson index and the five major poverty indices, the result shows that zakat can reduce income inequality and poverty (Ibrahim 2006).

Second, a research conducted by Mila Sartika (2008) entitled "Pengaruh pendayagunaan zakat produktif terhadap pemberdayaan mustahiq pada LAZ Yayasan Solo Peduli Surakarta". The method used in this study is quantitative with the simple regression tools. This research makes mustahiqg with livestock assistance at LAZ Foundation Care Solo as the subject of research, while the object is the income level of mustahiqq. Based on the results of this study, it can be seen that there is a significant influence between the amounts of funds disbursed to income of mustahiqq. So the higher the funds disbursed, the higher of the income generated by mustahiqq (Sartika 2008).

Third, a research conducted by Irfan Syauqi Beik (2009) entitled "Analisis peran zakat dalam mengurangi kemiskinan: studi kasus dompet dhuafa republika". The subject of this research is 50 mustahiqg at the Institute of Amil Zakat National Dompet Dhuafa Republika, while the object of this research is the level of poverty. This study uses several analysis tools, including head count ratio to find out the number and percentage of poor families, the ratio of poverty gap and the gap of income to know the depth level of poverty, and the index of sen and Foster Greer and Thorbecke (FGT) to measure the severity of poverty. Through this research, it can be seen that zakat able to reduce the number and percentage of poverty, depth and severity of poverty ( irfan Beik 2009).

Fourth, a research conducted by Firmansyah (2013) about "zakat as an instrument of poverty alleviation and income gap". The method used in this study is descriptive qualitative in which discuss three studies about the role of zakat for mustahiqq. In the first research by Beik (2010) conducted a study of 1195 households 
in the province of DKI Jakarta. The result of this research is mustahiqq income up to 9.82 percent which in general can improve the standard living of mustahiqq. Besides, the result of this study is the zakat able to reduce the poverty rate of mustahigq by 16.8 percent. Second research conducted by Beik et al (2011) using the study subjects of 1,639 mustahiqq from five different provinces. It is known that 21.11 percent of mustahiqq are able to move away from the poverty line. In a third study conducted by Mintarti et al (2012), using 821 poor households from 4,646 zakat recipient in jabodetabek as the subjects. The result is a poverty rate decrease to 10.79 percent. Based on the discussion conducted by Firmansyah, it can be concluded that productive zakat can give the impact in the form of poverty reduction and minimize the income gap (Firmansyah 2013).

Fifth, a research conducted by Rina Murniati and Irfan Beik in 2016 about the influence of zakat on human development index and poverty level of mustahiqq, case study about empowerment BAZNAS Bogor city. The subject of this study is BAZNAS Bogor city, while the object of this study is the level of income and poverty level of mustahiqq. By using statistical $t$ tools, it is found that the utilization of zakat decreases the poverty level of mustahiqg and gives an effect on the income level of mustahiqq (Rina Murniati 2016).

Sixth, a research conducted by Irfan Syauqi Beik and Caesar Pratama (2016) titled "Zakat impact on poverty and welfare of mustahiqq: CIBEST model approach". The research subjects were 121 mustahiqq households from four villages in Bogor district, while the object of the study was the condition before and after receiving the productive zakat funds. This study uses the CIBEST index to measure the material and spiritual side. The results of this study, on the index of the material poverty decrease by 49.6 percent, the index of the spiritual poverty decreased by 1.6 percent, the absolute poverty index decreased by 12.3 percent, and the welfare index increased by 63.7 percent. In other words productive zakat has a positive impact in reducing the poverty of mustahiqq households (I. S. Beik and Pratama 2016).

\section{METHODOLOGY}

The methodology used in this paper is descriptive qualitative methodology with content analysis approach. According to Berelson (1952) in (Stemler 2001), content analysis can be systematically defined as a replication technique used to clarify words from a text into several payload categories, based on the implicit rules. Meanwhile, according to Holsti (1969) in (Stemler 2001), content analysis is defined as a technique for interpreting and identifying a message characteristic specifically, objectively and systematically.

In approaching that content analysis, the authors use a method of tafsir that has been used by Ulamā' to explore the laws and wisdom from Quran. In this case, the authors combine between tafsì $r$ bi al-ra'yi and tafsì bi al-ma'thūr. This refers to the opinion of al-Suyūtī and al-Qard̄ōwī which described before, that the interpretation with modern science should still refer to the nas and tafsìr bi al-ma'thūr as well. Therefore, in this research the authors explore some of the leading tafsir literary, both classical and contemporary tafsi $r$. The classical tafsi $r$ books that the authors used as reference are Tafsīr Ibn Kathīr by Ismā'îl bin 'Umar bin Kathīr, Ma'ālim al-Tanzīl by Abū Muhammad al-Husain bin Mas' $\bar{u}$ al-Baghāwī, Mafātīh al-Ghaib by 'Umar bin al-Husain al-Rāzī. 
While the contemporary tafsì books which used as reference are Tafsìr al-Munìr by Dr. Wahbah al-Zuhailī and Tafsīr al-Sha'rāwōi by Muhammad Mutawallī al-Sha'rāwī.

\section{RESULT AND ANALYSIS}

The object of this research is al-Tawbah: 103, that is

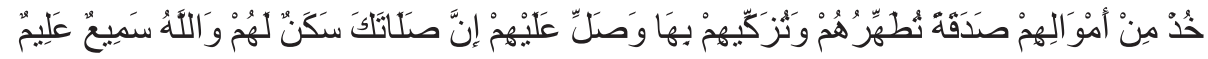

"Take Sadaqah (alms) from their wealth In order to purify them and sanctify them with it, and invoke Allâh for them. Verily! Your invocations are a source of security for them, and Allâh is All-Hearer, All-Knower." (QS. al-Tawbah: 103)

In sürah al-Tawbah: 103 above, there are two interesting sentences for our

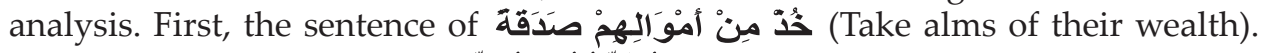

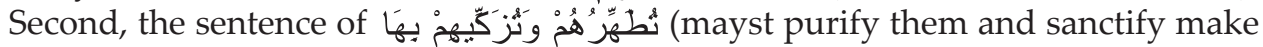
them grow). In the first sentence contains the concept of zakat, while in the second sentence contains the function of zakat. The second sentence in surah al-Tawbah: 103 above have a very strong connection with the first sentence. It has meaning that the function of zakat which describe in second sentence will run well if the concept of zakat described in first sentence well implemented.

\subsection{The Concept of Zakat}

In sürah al-Tawbah: 103, Allah started with Lafad خُ (take) which is the form of the command word (fi'il amr). According to al-Rāzì in his tafsìr book Mafätīh alGhaib, the use of the command word in the form (take) as a dähir show that the taking of zakat from muzakki is obligatory (Rāzi n.d.). The opinion of $a l-R \bar{a} z \bar{l}$ is in accordance with uṣul al-figh method which states that the word of command must be directed to the mandatory law as long as there isn't other Dalil that directs the order to other than mandatory law.

The object (mukhātab) of the command word (take) in that ayah is Rasulullah who commanded by Allah to take zakat from the rich (Dimashqi 1999). However, although the mukhatab (object) of the command in the ayah is Rasulullah, but the command also applies to all judges or authority after him (Zuhailī 1998). The context of the command to the Rasulullah in the ayah is the command to Rasulullah as the head of Islamic government at that time. Thus, that command also applies to the heads of state afterwards.

The above opinion is also supported by the attitude of $A b \bar{u}$ Bakar to the opponents of zakat in his era. Abu Bakar -who was the head of state or khalifah after Rasulullahwas very angry and even battled some Arabian who refused to pay zakat with argument that the obligation to pay zakat was no longer exist because Rasulullah has already death. In a Riwāyah Bukhāri and Muslim mentioned that Abū Bakar said

"By Allah! If they refuse to pay even young goat which they used to pay during the life-time of Rasulullah, I will fight with them for it."(HR. Bukhāri and Muslim)

In the implementation of zakat as describe above, the government can appoint some officers who handle the collection and distribution of zakat, known as amil zakat or 'ámilinn. This is as it was the assignment of Rasulullah who was a representation of the head of state at that time to the Mu'adz bin Jabal to take 
zakat in the Yaman. In the assignment, Rasulullah gave a message to Mu'adz to be presented to the Yaman residents. The message is

"Indeed Allah has enjoined on them, the Zakat. And it is to be taken from the rich amongst them and given to the poor amongst them" (Muttafaq 'Alaih).

In addition, the use of Lafad خُ خُ (take) in sürah al-Tawbah: 103 and Lafad نُؤَخَد (taken) in the above hadith also becomes a reinforcement that zakat is the right of the recipient (mustahiqq) to be taken from the rich (muzakkī). Thus, zakat is not a voluntary that is left entirely to the consciousness of each individual. In contrary, zakat is obligatory which when muzakki refuse to give it, then zakat can be taken by force as done by Abū Bakar. This is as confirmed by Allah in sürah alDzāriyyāt: 19

"and In their properties there was the Right of the beggar, and the Mahrûm (the poor who does not ask the others)" (QS. Al-Dzāriyyāt: 19)

There are two important wisdom proposed by al-Sha'rāwi in management of zakat by government, that is (Sha'rāwī n.d.):

1. The avoidance of mustahiq from disgrace for "raising their hand" to ask zakat from muzakki. With the management of zakat by government, the mustahiqq no longer need to "raise their hand" to ask zakat because they will directly receive it from the government.

2. Avoidance mustahiq especially Faqī and Miskīn from the negative psychological impacts that occur when receiving directly from muzakkī. For example, when the family mustahiqq A know that the muzakki who gave the zakat is family B, then it will give own psychological impact to family A. it could be a child from family A will feel inferior when dealing with children from family B because he knows that family $B$ is the person who gave zakat to his family. It is different when zakat is managed by the government, then there will be no poor people who feel contemptible and inferiority when dealing with the rich because they didn't know from whom the zakat their received. The poor know only that as a people, they get what their deserves from the government which supposed to prosper all his people.

Based on the above description, we can know that zakat in Islam is obligatory not voluntary. This assumption is important for the functioning of zakat in society's life and economy. In the context of sürah al-Tawbah: 103, the zakat system as

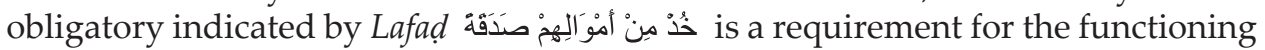

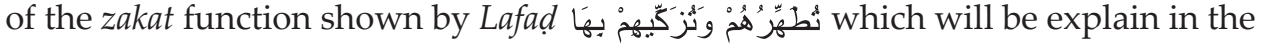
next discussion.

\subsection{The Function of Zakat in the Social and Economic Equality}

In the sürah Al-Tawbah: 103, Allah mentions two main functions of zakat, there are

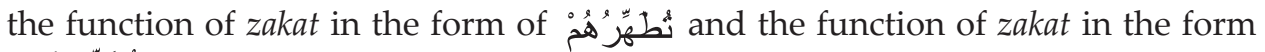
of 1 نز

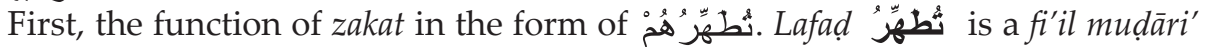

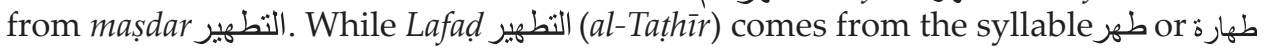
which means holy or clean. In Arabic grammar, Lafad طهارة can be used for clean

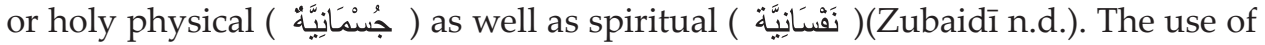
Lafad for spiritual holy is also often used in the Quran. One of them is 
"are the ones whose hearts Allâh does not want to purify (from disbelief and hypocrisy); for them there is a disgrace In This world, and In the Hereafter a great torment" (QS. AlMāidah: 41)

Based on this, we can interpret the the function of zakat in the form of التطهير in the sürah al-Tawbah: 103 as cleansing and purifying of the soul. In this case, zakat is able to cleanse the hearts those who pay zakat from the greedy and miserly which is bad characteristic of human nature. Allah said

"Say (to the disbelievers): "If You possessed the treasure of the Mercy of My Lord (wealth, money, provision, etc.), Then You would surely hold back (from spending) for fear of (being exhausted), and man is ever miserly!"(QS. Al-Isrā': 100)

In the other ayah, Allah is also said

"Even though men's souls are swayed by greed" (QS. Al-Nisā': 128)

As we have known, treasure is something that very precious and loved by human. In fact, sometime we find someone who loves treasure more than everything including family or even God. Therefore, it is no exaggeration if Rasulullah mentioned the treasure as a something green (خَضَرِ

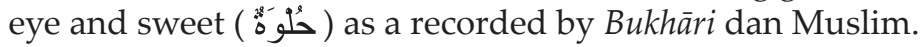

Excessive love of the treasure often invite greedy virus into human heart. This greed is describe by Rasulullah in a hadith recorded by Bukhāri

"Had the man been given a valley full of gold, he would have wanted the second again. If he is given the second one, he wants another third. No one can fill his stomach apart from the ground. Allah is receptive to anyone who wants to repent." (HR. Bukhäri no. 6438)

That greed in the end makes people reluctant to give his treasure to other even the smallest thing. It's more ironic when the little treasure gone, he is not as confused as when that little treasure asked by poor people (Faqīr or Miskinn). He will be very hard to give it.

From here, the obligation of zakat that has been established by Allah has an important role to gradually kill the viruses of greedy and miserly in the heart of human. With the existence of zakat, the rich are forced to give some of the treasure that Allah entrust to the person who needed. Obligations that charged continuously are expected to be able to get used to share and feel the lives of poor people. So the next time that rich not only pay zakat because of duty, but also he will give charity more than he pay zakat as has been done by the Prophet friends, Tābi'în and successor.

Besides cleansing and purifying the heart of muzakki from the greedy, zakat is also able to purify the heart of mustahiqq from envy, anger and jealous. This envy, anger and jealous are often triggered by high level of inequality. And then, this envy, anger and jealous become a main factor of criminality such as robbery. In this case, zakat is one of the instruments to distribute the wealth, which in Islam functioned to minimize the inequality. The small inequality leads to reduce the potential of criminalization. Thus, the existence of zakat is essentially able to keep the wealth of muzakki from the robbery because of the inequality. This is fit with hadith Rasulullah

"Keep your possessions (from destruction) by (issuing) zakat" (HR. Al-Ṭabrānī)

Awareness of zakat and the correct and optimal management of zakat are also capable to give a positive psychological impact to mustahiqq. The mustahiqq will feel the benefit from the existence of the rich people which their zakat become one 
of the income for mustahiqg. This, makes the envy, anger and jealous to the rich turn into gratitude and love for them. This is as stated by Rasulullah:

"The attitude of the heart is inclined to love those who do good to him and hate those who do bad to him." (HR. Al-Baihaqi dalam Shu'ab al-Iman 6: 2985).

In the social context of society, the role of zakat according to al-Qardāw $\bar{\imath}$ is able to provide the strong bond between the rich (muzakk $\bar{\imath})$ with the surrounding community. The bond will always be framed by love and combine with brotherhood and help each other (Qarawī 1973). At the end the bond will create a sense of secure, peace, and harmony between them. The sense of secure, peace, and harmony in this community will become one of the pillars of successful economic development.

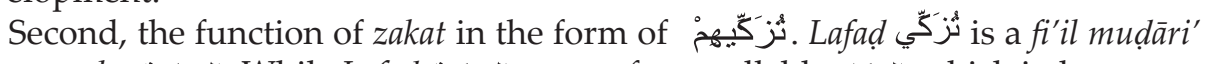

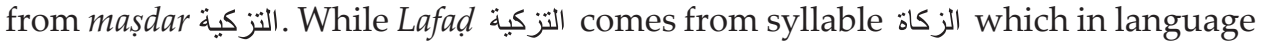

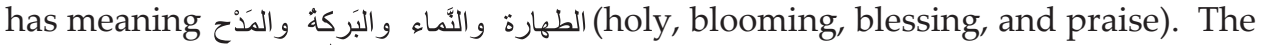
use of the word الزكاة for the four meanings is found in the Quran and hadith.

Based on the above, التزكية has a same meaning with التطهير. However, according to al-Rāzin, when التزكية called concurrently (affixed) with Lafad التطهير, there must be a difference between the two (Rāzi n.d.). This is because in the Quran there can be no repetition of the same Lafad without any different meaning or other implied utility.

Based on above description, there are three meaning given by mufassir for Lafad التزكية in the sūrah al-Tawbah: 103, that is (Zuhailī 1998) (Baghāwī 1997):

1. Zakat is able to raise the people degree who pays it from the Munäfiq to the mukhlis (people who feel ikhlash). This opinion based on the assumption that sürah al-Tawbah: 103 is a continuation of al-Tawbah: 101 which describe the Munāfiq people.

2. Lafad التزكية has the meaning مبالغة في التطهير وزيادة فيه (more purifying).

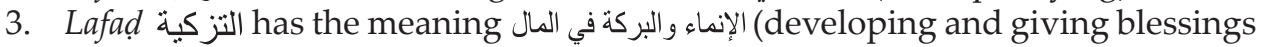
to the treasure). It's mean that Allah will make the loss of property due to zakat reason for develop, increase, and blessed of the treasure.

From various meaning about Lafad التزكية above, the authors agree with the third meaning. According to Ibn Mandzur, التزكية can also be derived from the

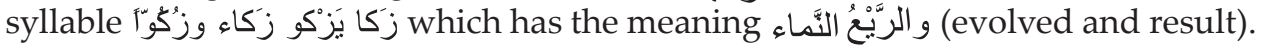

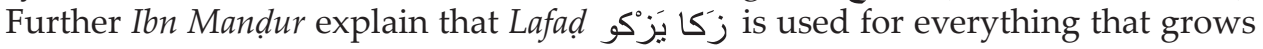
and develops (Mișrī n.d.). Moreover, in another ayah, Allah explains the functions of zakat and alms as a developers and adders of treasure.

"Allâh will destroy Ribâ (usury) and will give increase for Sadaqât (deeds of charity, alms, etc.)" (QS. Al-Baqarah: 276)

Lafad تيرنبي in the ayah above has the meaning of كثره ونماه (reproduce and develop)(Dimashqi 1999). In this case, the function of التزكية which is in the zakat, according to al-Sha'rāwi occurs in every element in it, for the recipient (mustahiqq), the giver (muzakkī) and the treasure itself (Sha'rāwī n.d.).

Based on the above, we can conclude that one of the roles of zakat is able to add and develop economically. The role of adding and developing is applicable for the recipient (mustahiqq), the giver (muzakkî), and the treasure itself. In the context of economy, the role of zakat to recipients (mustahiqq) and givers $(m u z a k k \bar{\imath})$ can be seen in the microeconomic outlook. While the role of zakat in 
adding and developing the treasure itself can be seen in the macroeconomic outlook.

The function of zakat as a micro can be seen from the role of zakat for thr recipient (mustahiq) and the giver (muzakkī). A very dominant group affected zakat is the mustahiqq, which their consumption level depend on the distribution of zakat (Sakti 2007). In other words zakat has a positive correlation on the consumption level of mustahiqq. It is described in a hadith

"Zakat fitrah is the cleansing of fasting people of wasted talk and sinful acts, and as feeding the poor" (HR. Abū Dāwōud)

In the above hadith, Rasulullah explained one of the function of zakat, that is as food for the poor (Miskin). In the wider context, the function of zakat as a food has the meaning of zakat serves an addition for the poor in order to fulfill their consumption of basic necessities. With the zakat, the purchasing power of the poor to fulfill their basic needs is increase. In the context of microeconomics, the increasing of purchasing power is an increasing in demand.

In the zakat system, the process of zakat is allocate property based on two principles, that is to produce welfare and generate income level (Rivai 2013). The increasing of mustahiqg income automatically increases the purchasing power of mustahiqq. Theoretically, the existence of zakat will increase the demand curve through the demand aggregate that increase due to the purchasing power of mustahiqq society driven by the distribution of zakat (Sakti 2007). It means that the distribution of zakat will increase the purchasing power from mustahiq, and it is in accordance with the result of the research of (Ibrahim 2006) dan (Sartika 2008)

The increasing of the demand curve as described above will certainly increase the price in the short time. However, the increasing of the price will has an impact of producer revenue. If it is assumed that this price increase information known to all market participants (symmetric information), then it will certainly attract new market participants to enter the market (Sakti 2007).

The entry of new market participants will increase the number of supply so it will increase the supply curve. As a result of the increase of the supply curve, then the price will be corrected. The equilibrium price after the zakat distribution will be relatively stable than compared to before the zakat distribution, but the number of goods has increased compared to before the zakat distribution. In addition, increasing demand for these goods will stimulate the production of goods and services (P3EI FE-UII 2016).

The positive effect of zakat on productivity and supply can also be seen from the enactment of zakat on money or idle financial assets (P3EI FE-UII 2016). Owners of unused property will be motivated to drain their wealth into the real sector so that zakat is only be taken on the yield, rather than its main assets. This is as conveyed by the Rasulullah

"Remember, those of you who take care of the orphan's treasure, should he develop it in commerce and do not allow it to be eaten by zakat" (HR. al-Turmudhī)

In the hadith, Rasulullah linked the prohibition to unemployed treasure by the application of zakat. Instead Rasulullah ordered to develop the treasure so that zakat can be taken from the results of treasury property rather than the main treasure. Thus, we can see how Rasulullah made zakat as an excuse for someone to always productivity the treasure and not let it idle. That increasing 
productivity is compatible with the result of research by (Rina Murniati 2016) and (Sartika 2008)

In contrast to zakat, taxes have a negative effect on supply and productivity. Sales tax or value added tax will increase the average total cost, and if the price stays at the original price level, then this increase in cost means a decrease in profit. This can be happen because the revenue total is fixed while the total cost increases. The decline in profits also led to a shrinking range of production scales, as a result of the increase in the burden to be borne by market participants. The decrease in the scale of production means a decrease in the number of products produced which also means a decrease in supply(Karim 2012). In other words, imposition of sales tax or value added tax can decrease productivity and supply of goods.

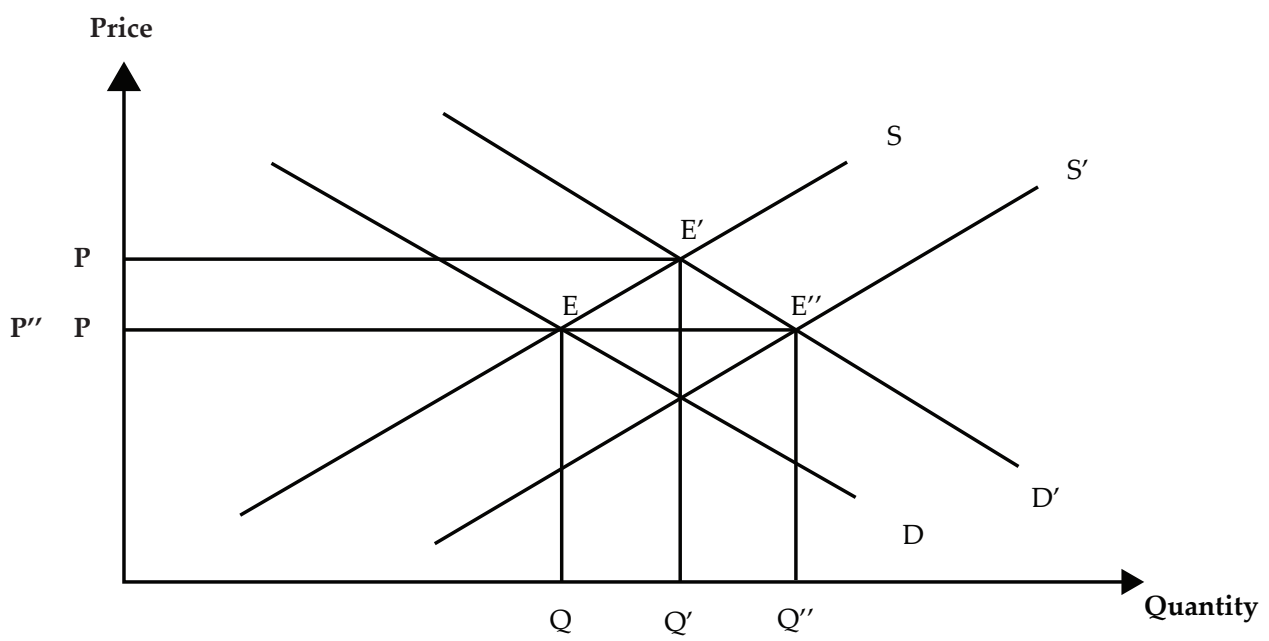

Source: Sakti, 2007

Figure 1.

Zakat Curve in The Economic

Based on the exposure of the micro zakat function, it is evident that zakat can influence the economic behavior of mustahiqg and muzakki. The following will be discussed using illustrations of demand and supply curves. From the side of mustahiqq, zakat can increase the purchasing powers which in the end also increase the demand. This will shift the demand curve from $D$ to $D$ 'so that the equilibrium point will shift from $E$ to $E^{\prime}$. Although the shift causes prices to rise from $P$ to $\mathrm{P}^{\prime}$, it only temporary. Because from the side of muzakki, zakat will increase the productivity and supply that will shift the supply curve from $S$ to $S^{\prime}$. The shift will form a new equilibrium point from $E$ 'to $E^{\prime \prime}$. At a new equilibrium point ( $\left.E^{\prime \prime}\right)$ the price will be corrected and become relatively stable compared to before the distribution of zakat but with a larger quantity.

The macro zakat function can be seen from the function of zakat for investment and wealth distribution. There are several key elements that must be considered to understand the effect of zakat on investment. One of them is zakat collected 
on money or idle financial assets, such as gold deposits or money that exceeds a period of time a year and sufficient the nishab, thus encouraging people to invest or produce (P3EI FE-UII 2016).

As has been explained before, zakat can encourage someone to manage and productive the treasure he has. In aggregate, it is able to encourage the investment. With the collected of zakat on stored treasure, that will be activated or invested (P3EI FE-UII 2016). Thus, zakat has a positive correlation with investment. The increasing in investment will ultimately increase the unit of production.

Contrary with the zakat that has a positive correlation with investment, Riba has a opposite correlation. Riba, which reflected in the interest rate, if its existence increases, it will cause a decrease in investment level. Interest rates as one of the financial instruments whose function is to control the money supply will greatly affect investment in the real sector. An increased interest rate will cause decreasing the money supply, so investment which is funding in the real sector will also decrease.

In addition, zakat also serves as one of the instruments of wealth distribution in Islam. As an instrument of wealth distribution, zakat has an important role in overcoming the problem of poverty. As we all know, one of the main concerns of development in developing countries is combat the source of the poverty and reduce the poverty (P3EI FE-UII 2016). Therefore, various development theories and economic policies were developed to reduce the poverty levels.

In general, there are several major causes of poverty, some of them are market inefficiency and imperfection, that is uneven distribution of wealth and income and economic and finance dualism which adds to the difficulty of achieving efficient market mechanisms. The market system will not automatically make a fair income distribution; and low human resource productivity that can be seen from the low level of education, the subtle high level of unemployment, and the low level of entrepreneurship (P3EI FE-UII 2016).

Income per capita of a country is calculated to be an indicator in determining economic growth. However, this economic growth does not guarantee that the increasing income enjoyed by every member of society equitably or evenly, does not reflect the high level of poverty, nor does it reflect how the process of improving the welfare is obtained fairly without harming the rights of certain groups of people and does not reflect whether welfare is followed in every aspect of life or not. There are at least two instruments of poverty alleviation agreed by Faqih, one of it is zakat (P3EI FE-UII 2016). Viewed from the economic aspect, zakat is useful to avoid the accumulation of property on a few people, distribute the treasures more justly and equitably, prospering of the weak, and expected to produce a better economic order.

Zakat is a duty to distribute some of the treasures that the distribution process strongly associated with the efforts to reduce the level of poverty. Of the eight groups of mustahiqq, all the groups are in weak condition and can't be allowed to do $M u^{\prime}$ 'amalah or transact through market mechanism (P3EI FE-UII 2016). Zakat is also a religious command that considered as worship or good deeds, but muzakki often indifferent to the benefits of the paid zakat. Yet the success indicator of zakat is not only seen from the paid zakat or not, but also how much the benefits of the paid zakat. There are some basic elements that must be considered to understand 
the effect of zakat on investment, one of that is a part of zakat distributed to muzakki in the form of working capital (P3EI FE-UII 2016).

The use of productive zakat funds can be an alternative of capital financing for the poor who in the previous income analysis, their business turnover can fulfill household expenditures (Prodi Ekonomi Islam FEB-UNPAD 2016). Then explained that in the distribution of zakat as a source of financing to micro enterprises, should pass the filter process first. The filter process as the initial stage to filter and select the recipient or mustahiqq, so that later will get a prospective entrepreneur who has prospects and who have no prospects. Entrepreneurs who have good prospects will get the facility. One of the aspect that should be seen is the spiritual aspect (morale). It can be accurately used to disclose all the information needed in the screening process or as a filter in the selection process and the preparation of the recipient.

Implementation of Islamic social fund system provides an adequate space for the recipients of zakat to fully concentrate in the management of their business (Prodi Ekonomi Islam FEB-UNPAD 2016). In the zakat system, there is no obligation for the recipient of zakat to recover the funds they received. However, there are demands socially and spiritually when the business has grown, then there is the obligation to set aside part of his wealth on the zakat sector. The proceeds of the zakat funds will be redistributed to the other mustahiqg in need. Therefore, zakat will play a significant role in decreasing the poverty level. This is compatible with the result of research by(Ibrahim 2006), ( irfan Beik 2009), (Firmansyah 2013), (I. S. Beik and Pratama 2016).

In general, the function of zakat for social and economic which contain in sürah al-Tawbah: 103 can be described in diagram bellow:

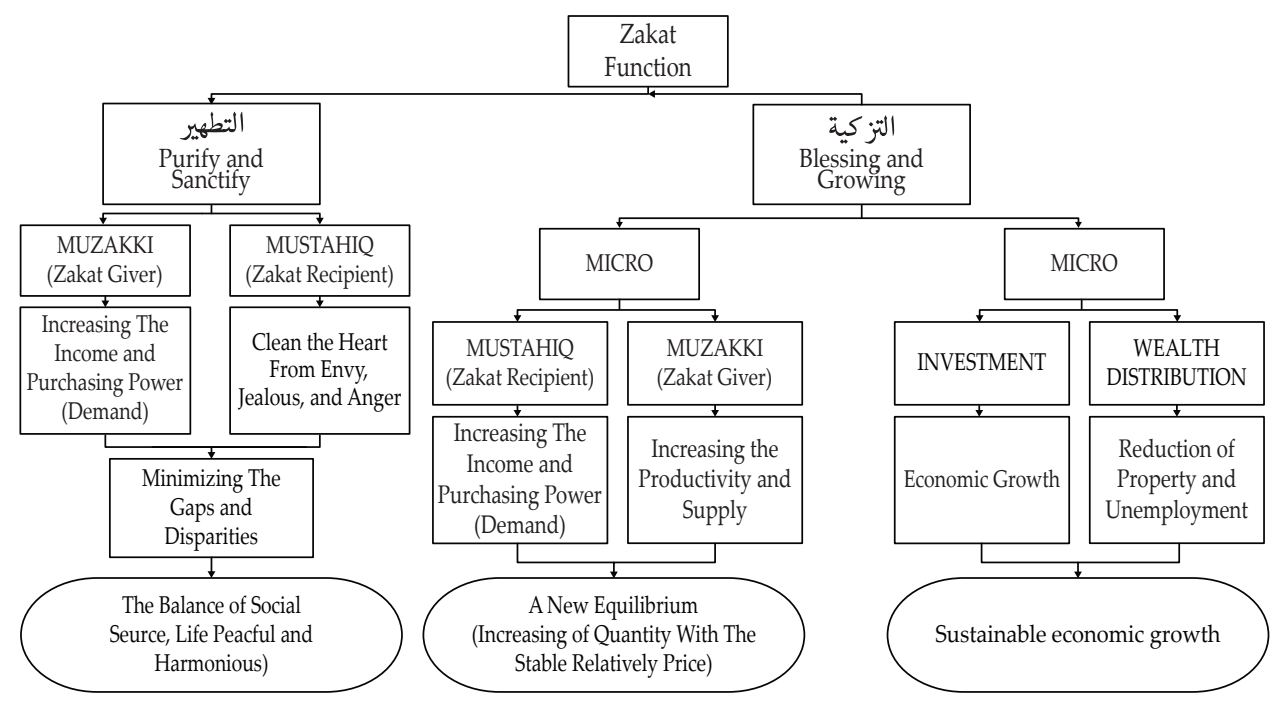

Source: Authors' Formulation from Various Sources, 2017

Figure 2.

The Diagram of Zakat Function in Social and Economic 


\section{CONCLUSION AND RECOMMENDATION FOR FUTURE RESEARCH 5.1 Conclusion}

Based on the analysis above, it can be concluded that the concept of zakat based on sūrah Al-Tawbah : 103 is zakat become an obligatory system, which the management should be done by the government; and the function of zakat for the social according to sürah Al-Tawbah : 103 is create a balance of life in society with the creation of a sense of secure, peace and harmony in the community. While the function of zakat for the economy is an increasing the purchasing power, productivity, investment and poverty reduction. This is the main capital for the sustainable economic growth. In this case, it is compatible with the previous research.

Based on the study findings, the following recommendations are provided. First, Indonesia as a country with the majority of the Muslim population is expected to make zakat as an obligatory system to moslem population. This is because the huge potential of zakat from the Muslim community of Indonesia which is the largest Muslim country in the world. Second, consequences of the implementation of zakat as an obligatory system is the management of zakat expected can be handled by the government. Zakat management by the government is able to optimize the function of zakat for social and economic community; third, research related to Islamic economic applications written in the Quran can use the tafsir approach which is the real khazanah in reviewing.

\section{REFERENCES}

Ayyūb, Hasan. 2004. Al-Hadīth Fi “Ulūm Al-Qur"ān Wa Al-Hadìth. Kairo: Dār al-Salām.

Baghāwī, Abū Muhammad al-Husain bin Mas'ūd. 1997. Ma'âlim Al-Tanzīl. Dār Țayyibah.

Beik, irfan. 2009. "Analisis Peran Zakat Dalam Mengurangi Kemiskinan: Studi Kasus Dompet Dhuafa Republika." Zakat \& Empowering - Jurnal Pemikiran dan Gagasan 2 (August): 45-53.

Beik, Irfan Syauqi, and Caesar Pratama. 2016. "Zakat Impact on Poverty and Welfare of Mustahik : A CIBEST." : 1-12.

Dimashqi, Ismā'il bin 'Umar bin Kathīr al. 1999. Tafsìr Al-Qur'ān Al-'Azīim. Dār Țaybah.

Firmansyah. 2013. "Zakat Sebagai Instrumen Pengentasan Kemiskinan Dan Kesenjangan Pendapatan." Jurnal Ekonomi dan Pembangunan 21(2): 179-90.

Ibrahim, Patmawati. 2006. "Economic Role of Zakat in Reducing Income Inequality and Poverty in Selangor." (January 2006).

Karim, Adiwarman A. 2012. Ekonomi Mikro Islam. Depok: Rajagrafindo Persada.

Miṣrī, Muhammad bin Manūr al. Lisān Al-'Arab. Bairut: Dār Șādir.

P3EI FE-UII. 2016. Pengelolaan Zakat Yang Efektif: Konsep Dan Praktik Di Berbagai Negara. Jakarta: Departemen Ekonomi dan Keuangan Syariah - Bank Indonesia. Prodi Ekonomi Islam FEB-UNPAD. 2016. Usaha Mikro Islami. Jakarta: Departemen Ekonomi dan Keuangan Syariah - Bank Indonesia.

Qarawī, Yusuf al. 1973. Figh Al-Zakāh. Bairut: Mu'assasah al-Risālah.

Qarāwi, Yusuf al. 2002. Fatwa-Fatwa Kontemporer Jilid 3. Jakarta: Gema Insani Press. 
Rāzi, 'Umar bin al-Husain al. Mafātīh Al-Ghaib. Bairut: Dār Ihyā' al-Turāth al-'Arabi. Rina Murniati, Irfan Syauqi Beik. 2016. "Pengaruh Zakat Terhadap Indeks Pembangunan Manusia Dan Tingkat Kemiskinan Mustahik: Studi Kasus Pendayagunaan BAZNAS Kota Bogor." Jurnal Al-Muzara'ah 2(2): 131-46.

Rivai, Veithzal dan Andi Buchari. 2013. Islamic Economics. Jakarta: Bumi Aksara.

Sakti, Ali. 2007. Ekonomi Islam : Jawaban Atas Kekacauan Ekonomi Modern. Paradigma \& Aqsa Publishing.

Sartika, Mila. 2008. "Pengaruh Pendayagunaan Zakat Produktif Terhadap Pemberdayaan Mustahiq Pada LAZ Yayasan Solo Peduli Surakarta." Jurnal La Riba (Jurnal Ekonomi Islam) 2(1): 75-89. http://journal.uii.ac.id/index.php/ JEI/article/view/163.

Sha'rāwī, Muhammad Mutawallī al. Tafsīr Al-Sha'rāwi. Maktabah al-Shāmilah.

Stemler, Steve. 2001. "An Overview of Content Analysis. Practical Assessment, Research \& Evaluation." 7(17). http://pareonline.net/getvn.asp?v=7\&n=17.

Suyūṭi, Jalāluddīn al. 1998. Al-Itqān Fi "Ulūm Al-Qur"ān. Bairut: al-Maktabah al-'Așriyyah.

Yūnus, Muhammad Kabīr. 2002. Dirāsāt Fi Ușūl Al-Tafsīr. Torabulis: Kulliyyah al-Da'wah al-Islāmiyyah.

Zubaidī, Abu al-Fāi Muhammad al. Tāj Al-'Arūs Min Jawāhir Al-Qāmūs. Mauqi' al-Warrāq.

Zuhailī, Wahbah bin Mușțafā al. 1998. Tafsīr Al-Munīr Fì Al-"Aqīdah Wa Al-Sharī"ah Wa Al-Manhaj. Bairut: Dār al-Fikr. 
This page is intentionally left blank 